\title{
Fine specificity of anti-MSP1 19 antibodies and multiplicity of Plasmodium falciparum Merozoite Surface Protein 1 types in individuals in Nigeria with sub-microscopic infection
}

Josiane Ngoundou-Landji ${ }^{1,2}$, Roseangela I Nwuba ${ }^{2 *}$, Chiaka I Anumudu ${ }^{2}$, Alexander B Odaibo ${ }^{2}$, Wenceslas D Matondo Maya ${ }^{3,4}$, Henrietta O Awobode², Christian M Okafor ${ }^{2,7}$, Olajumoke A Morenikeji², Adanze Asinobi ${ }^{6}$, Mark Nwagwu ${ }^{2}$, Anthony A Holder ${ }^{8^{*}}$, Francine Ntoumi ${ }^{4,5}$

\begin{abstract}
Background: The absence of antibodies specific for the $19 \mathrm{kDa}$ C-terminal domain of merozoite surface protein 1 (MSP1 $\left.{ }_{19}\right)$ has been associated with high-density malaria parasitaemia in African populations. The hypothesis that a high prevalence and/or level of anti-MSP1 19 antibodies that may inhibit erythrocyte invasion would be present in apparently healthy individuals who harbour a sub-microscopic malaria infection was tested in this study.
\end{abstract}

Methods: Plasma samples were collected from residents in a region in Nigeria hyperendemic for malaria, who had no detectable parasitaemia by microscopy. Using a competition-based enzyme-linked-immunosorbent assay with two invasion-inhibitory monoclonal antibodies (mAbs) 12.10 and 12.8, the levels and prevalence of specific antibodies were measured. The minimum multiplicity of infection was determined using PCR. The prevalence of anaemia was also measured.

Results: Plasma samples from $85 \%$ of individuals contained antibodies that bound to MSP1 19 . The inhibition of mAb 12.10 binding was strongly correlated with the prevalence (Spearman correlation test, $p<0.0001$ ) and mean titre of anti-MSP $1_{19}$ antibodies (Spearman correlation test, $\mathrm{p}<0.001$ ) in the samples. Comparing samples from individuals with multiple infection (group M) and single infection (Group S), group M contained a higher ( $p=0.04)$ prevalence of anti-MSP1 19 antibodies that competed with mAb 12.10. Using a logistic regression model, it was found that the presence of antibodies competitive with mAb 12.10 was affected negatively by anaemia $(p=0.0016)$ and positively by the carriage of multiple parasite genotypes ( $p=0.04)$.

Conclusions: In the search for correlates of protection against malaria, which will be essential to evaluate clinical trials of malaria vaccines based on MSP1, this study examines some potential assays and the factors that need to taken into account during their evaluation, using samples from individuals naturally exposed to malaria infection.

\section{Background}

Among many Plasmodium falciparum merozoite surface antigens, merozoite surface protein (MSP) 1 has been shown to be one of the major targets of antibodies that inhibit the invasion of red blood cells [1-3]. The protein

\footnotetext{
*Correspondence: rnwuba@yahoo.com; aholder@nimr.mrc.ac.uk ${ }^{2}$ Cellular Parasitology Programme, Department of Zoology, University of Ibadan, Nigeria

${ }^{8}$ Division of Parasitology, MRC National Institute for Medical Research, The Ridgeway, Mill Hill, London NW7 1AA, UK

Full list of author information is available at the end of the article
}

is present on the merozoite surface as a complex of polypeptides that includes a glycosylphosphatidyl inositol (GPI)-anchored $42 \mathrm{kDa} \mathrm{C}$-terminal fragment $\left(\mathrm{MSP}_{42}\right)$. During merozoite invasion into the red blood cell $\mathrm{MSP}_{42}$ is processed to yield 33- and $19-\mathrm{kDa}$ fragments $\left(M S P 1_{33}\right.$ and $M S P 1_{19}$, respectively). Only the GPI anchored $\mathrm{MSP}_{19}$ remains on the merozoite during erythrocytes invasion [4,5]. Some mouse monoclonal antibodies (mAbs) including 12.8 and 12.10 [6] that inhibit the invasion of red blood cells also inhibit the 
processing of $\mathrm{MSP}_{42}$ [7]. However, it is still not clear that this activity is a significant contribution to protective immunity acquired following exposure to the parasite [8].

Several immuno-epidemiological studies have yielded conflicting results with regards to the association between anti-MSP1 19 antibodies and protection against clinical malaria [9-15]. At least one study [16] has indicated that the total anti-MSP1 19 antibody titre is a poor indicator of malaria immunity, suggesting that antibody fine specificity is very important. It has been proposed that functional assays such as growth inhibition assays [17], inhibition of $\mathrm{MSP}_{42}$ processing [2] or Fc-mediated effector mechanisms [18] may provide a more informative readout to identify useful antibodies. The fine specificity of such functional antibodies may be examined using a numbers of methods including direct binding to antigen or modified antigen $[19,20]$ or competition assays using defined mAbs [21-23]. Using these approaches different classes of antibody have been defined and their epitopes partially mapped; for example $\mathrm{MSP}_{42}$ processing and merozoite invasion inhibitory antibodies, blocking antibodies that block the activity of invasion inhibitory antibodies, and neutral antibodies that have no effect on $\mathrm{MSP}_{42}$ processing and merozoite invasion $[2,8,20,24]$.

MSP $1_{19}$-specific invasion inhibitory activity has been associated with resistance to reinfection in Kenya [25]. However, parasite inhibitory activity is limited to a small subset of total anti-MSP1 $1_{19}$ antibodies. mAbs 12.8 and 12.10 have been used in several sero-epidemiological studies [16,21,23]. In one study in The Gambia [21], individuals with anti-MSP1 19 antibodies that compete with mAb 12.10 in a specific ELISA, were significantly less likely to have malaria infections with densities of $\geq$ 1,000 parasites $/ \mu$ l. In a study in Uganda, competition with $\mathrm{mAb} 12.10$ was highly correlated with resistance to high-density parasitaemia, but there was no such association with $\mathrm{mAb} 12.8$ [23]. The precise epitope mapping of both mAbs has been reported recently [26,27] and although there is considerable overlap of the two epitopes the data above suggest different functions for the corresponding antibodies [26].

A previous study carried out in the rural area of IgboOra, South-western Nigeria [16] showed no correlation between the level of naturally acquired anti-MSP1 $1_{19}$ antibodies and inhibition of $\mathrm{MSP}_{42}$ processing in plasma samples from $P$. falciparum infected children and adults. To test the hypothesis that in apparently healthy individuals who harbour sub-microscopic malaria parasite infections there would be a high prevalence and/or high level of anti-MSP1 $1_{19}$ antibodies that compete with mAbs 12.8 and 12.10 , further investigations in the Igbo-Ora population were carried out. To test this hypothesis, apparently healthy subjects without detectable parasites by thick and thin blood smears within all age groups were recruited and both the total antibody response to recombinant MSP $1_{19}$ and the fine specificity of anti-MSP $1_{19}$ antibodies using a competitive ELISA with mAbs 12.8 and 12.10 were assessed. In a second objective, an effect of multiplicity of infection was examined. As carriage of multiple P. falciparum clones can be a useful indicator of the immune status of the host $[28,29]$, the relationship between this parameter and the level of antibodies competing with the mAbs has also been investigated. Finally, the third objective of this work was to determine whether or not there was any association between the presence of specific invasion inhibitory antibodies, the anaemia status of the subject, and the carriage of multiple $P$. falciparum infections.

\section{Methods \\ Study area}

The cross-sectional study was conducted in Igbo-Ora, a rural area in south-western Nigeria; approximately 100 $\mathrm{km}$ from the state capital Ibadan. In Igbo-Ora malaria is hyperendemic with a prevalence of approximately $75 \%$ in children during the raining season from April to October and $55 \%$ to $60 \%$ during the dry season from November to March. The peak incidence was observed in November and August, with lower rates observed in July, September and October [30].

\section{Subjects and blood collection}

Enrollment was carried out in September and October 2000. Asymptomatic carriers of a P. falciparum infection were defined as individuals with detectable blood stage parasites and an axilliary temperature $<37.5^{\circ} \mathrm{C}$, who had not received any anti-malarial drug in the preceding fifteen days and who did not present any malaria symptoms for at least seven days following blood sampling. Children homozygous for the sickle cell trait (HbSS) as well as children with HbSC were excluded from the study. The protocol was explained to the assembled village population and informed consent was obtained individually from each participant or his/her parents; the study was approved by the Ethical Committee of University College Hospital, Ibadan, Nigeria.

Blood was collected by venipuncture into heparinized and EDTA containing tubes. Thick and thin blood smears were stained with Giemsa for microscopic detection of malaria parasites, examining 200 fields. Malaria parasites were counted relative to leukocytes, and a leukocyte count of $8,000 / \mu \mathrm{l}$ of blood was assumed. Blood slides were examined using the quality control procedures described elsewhere [30]. Red blood cells were separated from the plasma by centrifugation and both were stored at $-80^{\circ} \mathrm{C}$ prior to further analysis. 
Haemoglobin type was determined by electrophoresis on cellulose acetate gel with alkaline buffer. Packed cell volume (PCV) was determined using a haematocrit centrifuge (Hawksley and Sons, Ltd., Lancing, United Kingdom). Anaemia was defined according to the agedependent PCV levels published by the WHO (0-3 months: < 32\%, 6 months- 4 years: $<33 \%, 5-11$ years: $<34 \%$, $>12$ years: $<37 \%$; for adults, male: $<40 \%$ and female: $<37 \%)$.

\section{Genotyping of $P$. falciparum msp1}

DNA was extracted from blood cells using the QIAamp DNA blood mini kit (Qiagen) according to the manufacturer's procedure. Single and nested PCRs were performed to amplify the polymorphic sequence block 2 of P. falciparum msp1 as described previously [31]. Amplifications were performed in a final volume of $50 \mu \mathrm{l}$ and cloned or monomorphic parasite lines were used as positive template controls. The first round PCR amplification was performed using two microlitres of DNA and the primers 5'-AAGCTTTAGAAGATGCAGTATTGAC-3' and 5'-ATTCATTAATTTCTTCATATCCATC-3', designed on the conserved regions in sequence blocks 1 and 3 on either side of block 2 . The second round nested PCR amplification was carried out using $2 \mu \mathrm{l}$ of the primary amplified products. Primers were used for detecting the K1 (5' -AAGAAATTACTACAAAAGGTG-3' and 5'TGCATCAGCTGGAGGGCTTGCACCAGA-3'), RO33 (5'-AGGATTTGCAGCACCTGGAGATCT-3' and 5'GAGCAAATACTCAAGTTGTTGCA-3') and MAD20 (5'-TGAATTATCTGAAGGATTTGTACGTCT-3' and 5'-GAACAAGTCGAACAGCTGTTA-3') $m s p 1$ block 2 sequence families [32]. The amplifications were performed in a Biometra Uno II thermal cycler (Biometra, Göttingen, Germany) and the products were loaded onto a 1.5\% agarose gel (Peqlab Erlagen, Germany), electrophoresed and stained with ethidium bromide. The DNA was visualised under ultraviolet light and the fragment size polymorphism for each allelic family was determined. It was assumed that each PCR fragment represented at least one parasite genotype.

\section{$M S P 1_{19}$ recombinant protein}

The recombinant $P f M S P 1_{19}$ protein $\left(r M S P 1_{19}\right)$ was prepared by standard techniques as a glutathione $S$ transferase (GST) fusion protein by expression from a pGEX-3X plasmid as described previously [33] and it represents the sequence of the Wellcome parasite line [34] (EMBL accession number X02919).

\section{Enzyme-linked immunosorbent assay (ELISA)}

An indirect ELISA was performed to determine the prevalence and titre of IgG antibodies binding to $\mathrm{rMSP} 1_{19}$, as previously described [16]. Ninety six well-polystyrene microtitre plates (Costar, Corning Inc. NY) were coated with $0.5 \mu \mathrm{g} / \mathrm{ml} \mathrm{rMSP} 1_{19}$. Following incubation with diluted plasma samples, bound antibodies were detected with horseradish peroxidase (HRP)-rabbit anti-human IgG conjugate (Dako, Denmark) and ABTS/hydrogen peroxidase substrate solution by measuring the absorbance at $650 \mathrm{~nm}$. The plasma samples were diluted at a 1:25 ratio and then in two fold dilutions to 1:3200; the reciprocal end point titre (the highest dilution that gave an absorbance value greater than the background level measured with negative control samples) was log transformed, and data were expressed as geometric mean log reciprocal titres. The negative control samples were obtained from malaria-naïve residents of the United Kingdom.

\section{Competition ELISA assays}

The ability of polyclonal antibodies in the human plasma samples to compete with mAbs 12.8 and 12.10 for binding to $\mathrm{rMSP}_{19}$ was examined by competitive ELISA [22]. Initially each $\mathrm{mAb}$ was titrated against the rMSP $1_{19}$ and then used in the competition assay at a concentration that gave an absorbance reading just below the maximal absorbance for that antibody (i.e. just below the top of the titration curve). Microplate wells were coated with $0.1 \mu \mathrm{g}$ of $\mathrm{rMSP}_{19}$, then plasma at a dilution of 1:50 or 1:250 was added to duplicate wells, and the plates were incubated overnight at $4{ }^{\circ} \mathrm{C}$. A predetermined amount of $\mathrm{mAb}$ was then added and incubation continued overnight; the amount of bound $\mathrm{mAb}$ was determined as described previously [22]. Plasma samples were divided into two groups: non-competitive samples, which were those that inhibited the mAb binding by less than $50 \%$ at a 1:250 dilution and competitive samples, which were those that inhibited the mAb binding by more than $50 \%$ at a 1:250 dilution.

\section{Statistical analysis}

The multiplicity of infection (mean minimum number of different parasite genotypes per infected subject) was estimated by dividing the total number of $m s p 1$ PCR fragments representing different genotypes by the number of infected subjects. Infection was categorized as a nominal variable as follows: $M$ (multiple, $\geq 2$ parasite genotypes), S (single, 1 parasite genotype). The nonparametric Kruskall-Wallis and Mann-Whitney U tests were used to compare continuous variables between three (or more) and two groups, respectively. The chi square test was used to compare nominal data. The antibody response was divided into two groups: high competition/low $\mathrm{mAb}$ binding ( $\geq 50 \%$ inhibition of binding) and low competition/high mAb binding ( $<50 \%$ inhibition of binding). The effect of various parameters on a high or low competitive binding for both mAb 12.8 and 
12.10 was evaluated by logistic regression. Statistical analysis of data was performed using the JMP 5 statistical software. Differences were considered statistically significant at a $\mathrm{p}$ value of less than 0.05 .

\section{Results}

\section{Characteristics of subjects}

During the enrolment period, of 147 subjects recruited who had no detectable parasites by microscopy on Giemsa-stained thick and thin blood smears and who met the inclusion criteria, 143 had $P$. falciparum infections detectable by PCR with $m s p 1$-specific primers. Some characteristics of these subjects including sex, haemoglobin type, mean PCV and their use of bed and/ or window nets are given in Table 1. Fifty nine percent of recruited individuals were found to be anaemic, particularly amongst younger subjects: $63 \%$ of less than 1 year-olds, 33\% of 1 to 5 year-olds and $17 \%$ of 6 to 15 year-olds had PCVs below the WHO threshold, respectively. This decrease in anaemia with age was significant $(\mathrm{p}<0.0001, \mathrm{r}=0.56)$.

\section{Prevalence of $\lg \mathrm{G}$ antibodies reacting with $\mathrm{rMSP} 1_{19}$ protein}

Antibodies reacting with $\mathrm{rMSP}_{19}$ were detected in $85 \%$ of the individuals with sub-microscopic infections. There was a significant increase in the proportion of responders to $\mathrm{rMSP} 1_{19}$ protein $(\mathrm{p}<0.0001)$ and in the mean log titre of anti-MSP1 19 antibodies (Spearman correlation, $\mathrm{p}<0.0001$ ) with age, as shown in Table 2.
Human antibodies that compete with mAbs 12.10 and 12.8 for binding to rMSP1 $_{19}$

There was marked heterogeneity in the ability of polyclonal antibodies to compete with the $\mathrm{MSP} 1_{19}$-specific mAbs. The samples were divided into two groups: those containing highly competitive antibodies resulting in low binding of $\mathrm{mAb}$ to $\mathrm{rMSP}_{19}(\geq 50 \%$ inhibition of binding), and those containing poorly competitive antibodies resulting in high binding of $\mathrm{mAb}$ to $\mathrm{rMSP}_{19}(<50 \%$ inhibition of binding). As shown in Table 2, 39\% (57 of 147) of samples contained antibodies that were highly competitive to $\mathrm{mAb} 12.10$ binding to $\mathrm{rMSP}_{19}$. The 1 to 5 year-old age group contained the lowest prevalence of antibodies competitive with mAb 12.10 and although the inhibition of mAb 12.10 binding varied between age groups the difference was not significant. The inhibition of mAb 12.10 binding correlated strongly with the prevalence of total anti-MSP1 19 antibodies (Spearman correlation test, $\mathrm{p}<0.0001$ ) and with the mean titre of anti-MSP1 19 antibodies (Spearman correlation test, $\mathrm{p}<$ 0.001) (Table 3). Forty-six of the 147 samples (31\%) contained antibodies that competed with $\mathrm{mAb} 12.8$, and there was a correlation between the presence of such antibodies and age $(\mathrm{p}<0.001)$. There was also a strong correlation of competition with mAb 12.8 and the prevalence and mean titre of polyclonal anti-MSP1 19 antibodies ( $\mathrm{p}<0.0001)$ (Tables 2 and 3). Overall, plasma samples containing antibodies highly competitive with both mAbs were also those with the highest titres of total anti-MSP1 19 antibodies (Table 3).

Table 1 Characteristics of the subjects with $P$. falciparum sub-microscopic infections in Igbo-Ora village, Nigeria

\begin{tabular}{|c|c|c|c|c|c|}
\hline Factor & Number of subjects & ${ }^{\mathrm{a}} \operatorname{Sex}(\mathrm{F} / \mathrm{M})$ & ${ }^{\mathrm{b}}$ Nets (\%) & ${ }^{c} \mathrm{PCV}$ & ${ }^{d} p$ \\
\hline \multicolumn{6}{|c|}{ Age (years) } \\
\hline$<1$ & 38 & 20/18 & $32(84)$ & $31.7(6.8)$ & $<0.0001$ \\
\hline $1-5$ & 24 & $16 / 8$ & $24(100)$ & $33.4(2.7)$ & - \\
\hline $6-15$ & 36 & $20 / 16$ & $26(72)$ & $37.0(3.7)$ & - \\
\hline$>15$ & 49 & $37 / 12$ & $38(77)$ & $39.5(4.5)$ & - \\
\hline \multicolumn{6}{|c|}{ Haemoglobin phenotype } \\
\hline AA & 135 & $85 / 50$ & $111(82)$ & $34.7(5.7)$ & ref \\
\hline AS & 11 & $7 / 4$ & $8(73)$ & $38.2(4.7)$ & 0.14 \\
\hline$\underline{A C}$ & 1 & $1 / 0$ & $1(100)$ & 30 & nd \\
\hline \multicolumn{6}{|c|}{${ }^{\mathrm{e}}$ Minimum number of MSP1 genotypes } \\
\hline 0 to $1^{*}$ & 74 & $48 / 26$ & $62(84)$ & $34.6(5.3)$ & 0.86 \\
\hline 2 to 3 & 68 & $41 / 27$ & $54(79)$ & $35.0(6.1)$ & - \\
\hline 4 to 5 & 5 & $4 / 1$ & $4(80)$ & $35.8(2.3)$ & - \\
\hline Total & 147 & $93 / 54$ & $120(82)$ & $34.8(5.6)$ & \\
\hline
\end{tabular}

a Sex: $F$, female; $M$, male.

${ }^{b}$ Nets: indicates the use of bed and/or window nets; actual numbers and proportion of subjects (\%).

c PCV: mean packed cell volume (SD).

${ }^{\mathrm{d}} \mathrm{P}$ value for differences in PCV; nd: not done.

e Number of MSP1 genotypes was determined by PCR, the presence of 1 or more indicates the presence of parasites.

*Four samples did not produce a PCR product with the MSP1 primers. 
Table 2 Relationship between subjects' age, titre of anti-MSP1 antibodies, inhibition of binding of specific monoclonal antibodies and multiplicity of infection

\begin{tabular}{|c|c|c|c|c|c|c|c|c|}
\hline \multirow[t]{2}{*}{ Age (years) } & \multirow[t]{2}{*}{ Total Number of Subjects } & \multicolumn{2}{|c|}{${ }^{\mathrm{a} A n t i b o d i e s ~ t o ~ r M S P 1}$} & \multirow{2}{*}{$\begin{array}{c}{ }^{\mathrm{b}} \mathrm{mAb} 12.10 \\
\mathrm{H}(\%) \\
\end{array}$} & \multirow{2}{*}{$\begin{array}{c}\text { mAb12.8 } \\
H(\%) \\
\end{array}$} & \multicolumn{3}{|c|}{ Infection } \\
\hline & & Responders (\%) & Mean Log titre & & & $M$ & $S$ & MOI \\
\hline$<1$ & 38 & $23(61)$ & 2.21 & $7(18)$ & $8(21)$ & 14 & 23 & 1.5 \\
\hline $1-5$ & 24 & $20(83)$ & 2.35 & $2(8)$ & $7(29)$ & 12 & 11 & 1.8 \\
\hline $6-15$ & 36 & $34(94)$ & 2.69 & $33(92)$ & $13(36)$ & 27 & 8 & 2.2 \\
\hline$>15$ & 49 & $48(98)$ & 2.94 & $15(31)$ & $18(37)$ & 20 & 28 & 1.5 \\
\hline Total & 147 & $125(85)$ & 2.60 & 57 (39) & $46(31)$ & 73 & 70 & 1.7 \\
\hline
\end{tabular}

${ }^{a}$ Antibodies to rMSP1: Responders is the number of subjects with antibodies against recombinant MSP1,(\%) is the percentage of the total.

${ }^{\mathrm{b}} \mathrm{mAb12.10}$ and $\mathrm{mAb}$ 12.8: $\mathrm{H}$ refers to the number of individuals with antibodies highly competitive with the $\mathrm{mAb}$; (\%) is the percentage of the total.

Infection: M refers to individuals with two or more parasite clones; $S$ refers to individuals with only one parasite type detected. MOI is the mean multiplicity of infection based on MSP1 block 2 alleles.

\section{Genetic diversity in msp1 sequence block 2 and multiplicity of infection}

It was of interest to determine whether or not multiplicity of infection (MOI), and the numbers of different MSP1 types affected either the total amount of $M S P 1_{19}-$ specific antibody or of antibody that competed with the mAbs, and therefore the number of $m s p 1$ sequence block 2 types in the samples was used as a marker for MOI and MSP1 polymorphism in each individual. Genotyping of the polymorphic sequence block 2 revealed that RO33 was the predominant allele with $57 \%$ of the total, with the K1 and MAD20 allelic families representing $26 \%$ and $17 \%$, respectively. Based on size polymorphism, only one RO33 allele was detected whereas the MAD20 and K1 families contained 8 and 13 distinct alleles, respectively (Figure 1). There was no preferential distribution of allelic families between age-groups. The mean minimum MOI based on the number of msp1 genotypes detected for individuals in each age-group is shown in Table 2. The highest MOI was found in the 6 to 15 years age group. Seventy-three of 147 (51\%) isolates were found to have more than one P. falciparum genotype. There was no significant influence of age on the proportion of individuals with multiple versus single infections (denoted by $\mathrm{M}$ and $\mathrm{S}$, respectively in Table 2) or on MOI. Overall, no correlation between MOI and the mean log titre of anti-MSP1 $1_{19}$ antibodies was detected. Similarly the MOI was not correlated with inhibition of mAb 12.10 binding. However, comparing the two groups $M$ (multiple infection) and $S$ (single infection), there was a higher prevalence of antibodies that competed with mAb 12.10 in samples from group $\mathrm{M}$ (Table 3, $\mathrm{p}=0.04$ ).

Relationship between MOI, anaemia, and the inhibition of mAb binding

The proportion of individuals with anaemia decreased with age (Figure 2). Using logistic regression, the association of anaemia and the carriage of multiple P. falciparum genotypes on the total MSP1 $1_{19}$-specific antibody

Table 3 The multiplicity of $P$. falciparum infection and mean titer of anti-MSP1 antibodies, in subjects with antibodies that are either highly competitive $(\mathrm{H})$ or poorly competitive $(\mathrm{L})$ with the specific monoclonal antibodies

\begin{tabular}{|c|c|c|c|c|c|c|c|c|c|}
\hline \multirow[t]{2}{*}{${ }^{\mathrm{a}}$ Monoclonal antibody } & \multicolumn{2}{|c|}{ Number of subjects } & \multicolumn{3}{|c|}{${ }^{c}$ Infection } & \multicolumn{4}{|c|}{${ }^{\mathrm{d}}$ Antibodies to rMSP1 } \\
\hline & Total $n=147$ & ${ }^{b}$ Infected & $M$ & $\mathrm{~S}$ & MOI & Prevalence & $P$ & Mean log titre & $P$ \\
\hline \multicolumn{10}{|l|}{12.8} \\
\hline Poorly competitive (L) & 100 & 99 & 50 & 49 & 1.73 & $78 \%$ & 0.0006 & 2.3 & 0.0001 \\
\hline Highly competitive $(H)$ & 46 & 43 & 22 & 21 & 1.65 & $100 \%$ & & 3.2 & \\
\hline \multicolumn{10}{|l|}{12.10} \\
\hline Poorly competitive (L) & 90 & 87 & $38^{*}$ & 49 & 0.86 & $77 \%$ & 0.002 & 2.4 & 0.0001 \\
\hline Highly competitive $(\mathrm{H})$ & 57 & 56 & 35 & 21 & 0.98 & $96 \%$ & & 2.9 & \\
\hline \multicolumn{10}{|l|}{12.8 and 12.10} \\
\hline Poorly competitive (L) & 75 & 74 & $33 * *$ & 41 & 1.62 & $73 \%$ & 0.0007 & 2.3 & 0.0001 \\
\hline Highly competitive $(H)$ & 32 & 31 & 18 & 13 & 1.77 & $100 \%$ & & 3.2 & \\
\hline
\end{tabular}

${ }^{a}$ Monoclonal antibody. mAb12.10 and mAb 12.8: $\mathrm{L}$ and $\mathrm{H}$ refer to the number of individuals with antibodies that are either poorly competitive or highly competitive with the monoclonal antibodies, respectively.

bInfected: number of subjects positive by PCR.

'Infection: M refers to individuals with two or more parasite clones, S refers to individuals with only one parasite type detected. MOI is the mean multiplicity of infection based on MSP1 block 2 alleles.

${ }^{\mathrm{d}}$ Antibodies to rMSP1: Prevalence is the number of subjects with antibodies against recombinant MSP1 as a percentage of the total. 


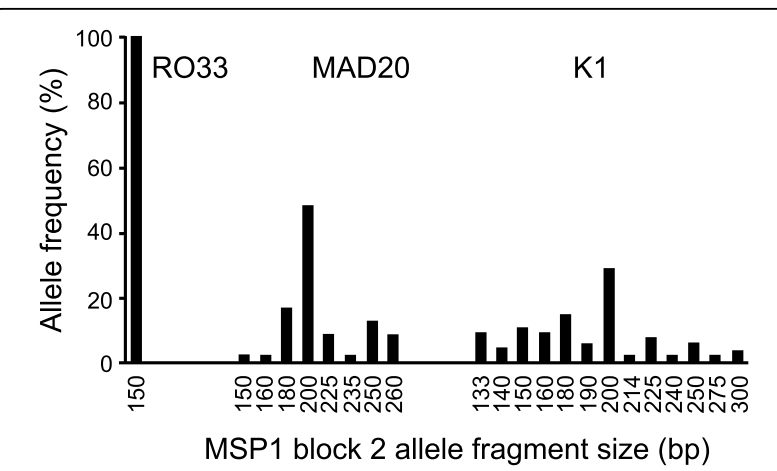

Figure 1 Distribution and prevalence of MSP1 alleles within sequence block 2 that were identified in the cross sectional survey. The different alleles fall into 3 different sequence families (RO33, MAD20, and K1) within which there are size polymorphisms identified by the size of the PCR amplified fragment (shown in base pairs, bp).

and the competitive activity with mAbs 12.10 and 12.8 were examined. Anaemia was significantly associated with total anti-MSP1 $1_{19}$ antibody $(\mathrm{p}=0.0016)$ with a low prevalence of antibodies that competed with mAb 12.10; whereas harbouring more than 1 parasite genotype (group $\mathrm{M})$ was associated $(\mathrm{p}=0.04)$ with a greater prevalence of antibodies that competed with mAb 12.10. This was not observed with MAb 12.8: the presence of antibody competitive with mAb 12.8 was influenced neither by the presence of multiple P. falciparum genotypes nor by anaemia.

\section{Discussion and Conclusions}

The first candidate malaria vaccines based on MSP1 are now being evaluated in clinical studies [35]. However, in view of the disappointing results in the first MSP1

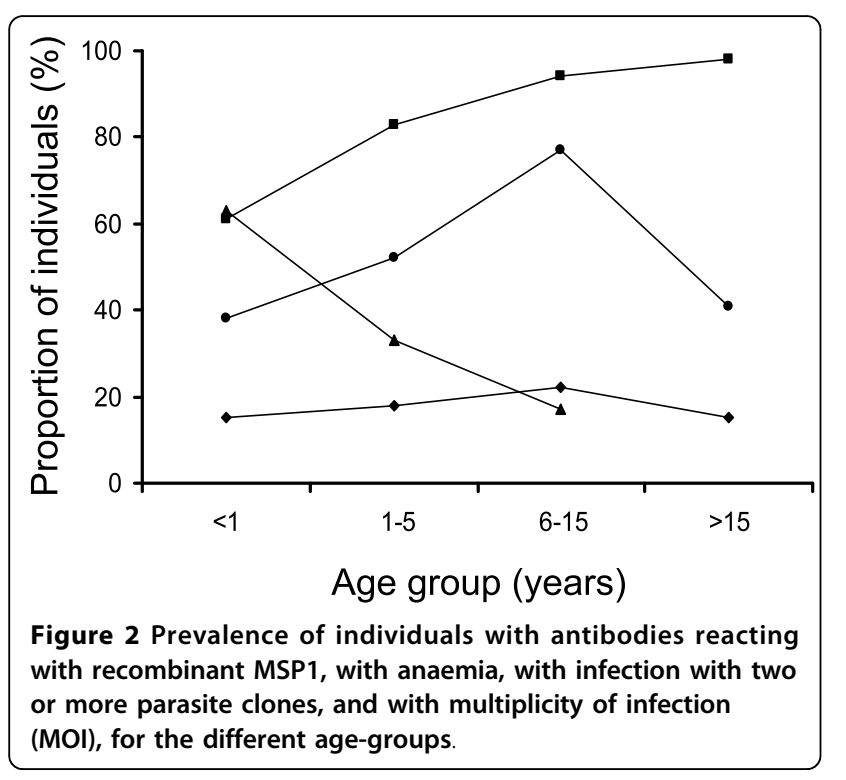

clinical trial in Kenya [36], there is an urgent need to define useful correlates of protective immunity and surrogate assays to evaluate malaria vaccines based on MSP $_{19}$ and other parts of the molecule.

The two mAbs 12.10 and 12.8, which inhibit the invasion of red blood cells and have overlapping epitopes [26], have been found to be useful in field studies to discriminate the potential contribution of each specificity to protection against clinical malaria or high-grade parasitaemia $[21,23]$. Asymptomatic carriage of parasites by young children as well as adults [37] reflects their ability to control the malaria infection through the presence of effective innate or acquired immune mechanisms. Therefore it was proposed that in the samples from such individuals, with a parasitaemia undetectable by microscopy, that there would be antibodies which would be highly effective at inhibiting parasite invasion of red blood cells, as reflected by higher competition with the mAbs 12.8 and 12.10 for binding to MSP $1_{19}$. In addition, it was of interest to evaluate whether or not there is an association between the level of antibodies that inhibit red blood cell invasion (assessed indirectly by the competition with the $\mathrm{mAbs}$ ) and the carriage of sub-microscopic infections comprised of multiple parasite clones, and representing an antigenically diverse parasite population.

In our Nigerian cohort, $85 \%$ of plasma samples contained anti-MSP $1_{19}$ antibodies. Both the prevalence and the mean titre of anti-MSP $1_{19}$ antibodies were significantly correlated with the age of the donor. This finding differs from that in a previous report from the same area [16], which noted a decline in the $M S P 1_{19}$-specific antibody titre with age in samples collected in the rainy season, whereas in samples collected in the dry season higher antibody titres were observed for children of six years of age or older than for younger children. In studies carried out in the Gambia and Uganda, the prevalence and mean anti-MSP1 19 antibody levels did not increase with age $[21,23]$. This discrepancy between the studies may be explained by differences in the intensity of malaria transmission, in the time of sample collection (seasonal variation) or in study design. Indeed, in the Gambian and Ugandan studies, individuals were followed up for some weeks and the objective was to search for association between outcome of the infection and reinfection and high parasite load. In our crosssectional survey, parasitaemia was a controlled parameter.

In the competition ELISA, 39\% and 31\% of samples contained antibodies that strongly inhibited the binding of $\mathrm{mAb} 12.10$ and $\mathrm{mAb} 12.8$, respectively. The inhibition of mAb 12.8 binding correlated positively with the titre of total anti-MSP1 19 antibodies as also found in Uganda, but not in The Gambia [23]; no influence of the age of the donor was found in these studies. Whilst competition with mAb 12.10 also correlated positively 
with total anti-MSP1 19 antibody titres in the Nigerian samples, there was no significant change in the prevalence of these competing antibodies with age as observed in the other African sites [21,23].

The mAbs 12.8 and 12.10 are antibodies that inhibit the secondary processing of MSP1 as well as the invasion of red blood cells. Previously this functional antibody activity was detected in samples similar to those we report on here [16] and this activity did not correlate with the titre of total anti-MSP1 19 antibody. Although a competition ELISA assay with mAbs 12.8 and 12.10 might be expected to provide a surrogate read-out for this function the situation is complicated by the potential presence of so-called blocking antibodies that compete with 12.8 and 12.10 , but do not themselves inhibit MSP1 processing or erythrocyte invasion [24].

In malaria endemic regions, anaemia has multiple causes e.g. polyparasitism, poor nutrition or immune depression. It can also result from both acute and chronic malaria [38]. A high MOI is considered to reflect acquired immunity or premunition [39] and to reduce the risk of clinical malaria and morbidity $[28,29]$, in part by selection against virulent parasites. However, May et al [40] showed that a high multiplicity of P. falciparum infection can be associated with an increased risk of anaemia. Here, in infants and older children with sub-microscopic infection, no association was found between MOI and anaemia status. However, the multiplicity of infection may have been underestimated [29] because only one blood sample was collected per individual and fluctuations in sequestered parasite populations and the sensitivity of the PCR method [41] may limit detection at low parasitaemia. In addition, the use of a single genetic marker can only provide a minimum estimate of diversity in the parasite population.

Immune responses (e.g. production of various cytokines) that vary with different parasite strains may contribute to the unequal impact of distinct parasite genotypes on haemoglobin levels.

An evaluation of the association of non severe malarial anaemia and $P$. falciparum polyclonal infections on the prevalence of antibodies which compete with $\mathrm{mAb}$ 12.10 showed that anaemia and carriage of multiple infections had a negative and a positive association, respectively. This association was not found for the prevalence of antibodies competing with mAb 12.8 binding. Interestingly, the possession of anti-MSP $1_{19}$ antibodies that compete with mAb 12.10 and not 12.8 has been associated with resistance to high-density parasitaemia $[21,23]$. These observations support not only the proposed importance of antibody fine specificity in playing a major role in protection against parasite load but also suggest a differential contribution of the overlapping specificities identified so far.

\section{List of abbreviations}

GPI: glycosylphosphatidyl inositol; GST: glutathione S-transferase; HRP: horse radish peroxidise; MSP: Merozoite Surface Protein; mAb: monoclonal antibody; MOI: multiplicity of infection

\section{Acknowledgements}

We thank the people of Igbo-Ora for their cooperation and participation in the study. We thank Mr. E.O. Koyejo for participating in coordinating the entire field work at Igbo-Ora. We are grateful to Dr. Bertrand Lell for his contribution in statistical analysis

JNL was a fellow of TWAS (Third World Academy of Sciences). FN was a fellow of Alexander von Humboldt Foundation. WDMM is a recipient of a RTG/TDR Grant (A30752). RIN and FN are members of MIMPAC (Malaria Immunology and Pathogenesis Consortium). AAH is funded by the UK Medical Research Council (U117532067). This study received financial support under the Multilateral Initiative on Malaria (MIM) project A10581 through the UNICEF/UNDP/World bank/WHO Special Programme for Research and Training in Tropical Diseases (TDR).

\section{Author details}

'Université des Sciences et Techniques de Masuku, Franceville, Gabon. ${ }^{2}$ Cellular Parasitology Programme, Department of Zoology, University of Ibadan, Nigeria. ${ }^{3}$ Unité de Recherches Médicales, Hôpital Albert Schweitzer Lambaréné, Gabon. ${ }^{4}$ Department of Parasitology, Institute for Tropical Medicine, University of Tübingen, Germany. ${ }^{5}$ Fondation Congolaise pour la Recherche Médicale/Université Marien Ngouabi, Republic of Congo. ${ }^{6}$ College of Medicine, University of Ibadan, Nigeria. ${ }^{7}$ College of Arts and Science, Northwest University, Kirkland WA 98033, USA. ${ }^{8}$ Division of Parasitology, MRC National Institute for Medical Research, The Ridgeway, Mill Hill, London NW7 1AA, UK.

\section{Authors' contributions}

J N-L, RIN, FN, MN, CIA, AA, WDMM, and AAH made substantial contributions to the conception and the design of the study, or acquisition, analysis and interpretation of data; $\mathrm{HOA}$ and $\mathrm{ABO}$ were involved in drafting the manuscript or revising it critically for content; and RIN, AAH and FN gave final approval of the version to be published; all authors read and approved the final manuscript.

Received: 20 July 2010 Accepted: 18 October 2010

Published: 18 October 2010

\section{References}

1. de Koning-Ward TF, O'Donnell RA, Drew DR, Thomson R, Speed TP, Crabb BS: A new rodent model to assess blood stage immunity to the Plasmodium falciparum antigen merozoite surface protein $1_{19}$ reveals a protective role for invasion inhibitory antibodies. J Exp Med 2003, 198:869-875

2. Guevara Patino JA, Holder AA, McBride JS, Blackman MJ: Antibodies that inhibit malaria merozoite surface protein-1 processing and erythrocyte invasion are blocked by naturally acquired human antibodies. J Exp Med 1997, 186:1689-1699.

3. O'Donnell RA, de Koning-Ward TF, Burt RA, Bockarie M, Reeder JC, Cowman AF, Crabb BS: Antibodies against merozoite surface protein (MSP)-1(19) are a major component of the invasion-inhibitory response in individuals immune to malaria. J Exp Med 2001, 193:1403-1412.

4. Blackman MJ, Heidrich HG, Donachie S, McBride JS, Holder AA: A single fragment of a malaria merozoite surface protein remains on the parasite during red cell invasion and is the target of invasion-inhibiting antibodies. J Exp Med 1990, 172:379-382.

5. Holder AA, Sandhu JS, Hillman Y, Davey LS, Nicholls SC, Cooper H, Lockyer MJ: Processing of the precursor to the major merozoite surface antigens of Plasmodium falciparum. Parasitology 1987, 94:199-208.

6. McBride JS, Heidrich HG: Fragments of the polymorphic Mr 185,000 glycoprotein from the surface of isolated Plasmodium falciparum merozoites form an antigenic complex. Mol Biochem Parasitol 1987, 23:71-84.

7. Blackman MJ, Scott-Finnigan TJ, Shai S, Holder AA: Antibodies inhibit the protease-mediated processing of a malaria merozoite surface protein. Exp Med 1994, 180:389-393. 
8. Holder AA: The carboxy-terminus of merozoite surface protein 1: structure, specific antibodies and immunity to malaria. Parasitology 2009, 136:1445-1456

9. Branch $\mathrm{OH}$, Udhayakumar $\mathrm{V}$, Hightower AW, Oloo AJ, Hawley WA, Nahlen BL, Bloland PB, Kaslow DC, Lal AA: A longitudinal investigation of $\lg G$ and $\lg M$ antibody responses to the merozoite surface protein-1 19 kiloDalton domain of Plasmodium falciparum in pregnant women and infants: associations with febrile illness, parasitemia, and anemia. Am J Trop Med Hyg 1998, 58:211-219.

10. Dodoo D, Aikins A, Kusi KA, Lamptey $H$, Remarque E, Milligan $P$ Bosomprah S, Chilengi R, Osei YD, Akanmori BD, Theisen M: Cohort study of the association of antibody levels to AMA1, MSP1 $1_{19}, M S P 3$ and GLURP with protection from clinical malaria in Ghanaian children. Malar J 2008, 7:142.

11. Dodoo D, Theander TG, Kurtzhals JA, Koram K, Riley E, Akanmori BD, Nkrumah FK, Hviid L: Levels of antibody to conserved parts of Plasmodium falciparum merozoite surface protein 1 in Ghanaian children are not associated with protection from clinical malaria. Infect Immun 1999, 67:2131-2137.

12. Egan $A F$, Burghaus $P$, Druilhe $P$, Holder AA, Riley EM: Human antibodies to the $19 \mathrm{kDa}$ C-terminal fragment of Plasmodium falciparum merozoite surface protein 1 inhibit parasite growth in vitro. Parasite Immunol 1999 21:133-139.

13. Hogh B, Marbiah NT, Burghaus PA, Andersen PK: Relationship between maternally derived anti-Plasmodium falciparum antibodies and risk of infection and disease in infants living in an area of Liberia, west Africa, in which malaria is highly endemic. Infect Immun 1995, 63:4034-4038.

14. Kitua AY, Urassa H, Wechsler M, Smith T, Vounatsou P, Weiss NA, Alonso PL, Tanner M: Antibodies against Plasmodium falciparum vaccine candidates in infants in an area of intense and perennial transmission: relationships with clinical malaria and with entomological inoculation rates. Parasite Immunol 1999, 21:307-317.

15. Murhandarwati EE, Wang L, Black CG, Nhan DH, Richie TL, Coppel RL: Inhibitory antibodies specific for the 19-kilodalton fragment of merozoite surface protein 1 do not correlate with delayed appearance of infection with Plasmodium falciparum in semi-immune individuals in Vietnam. Infect Immun 2009, 77:4510-4517.

16. Nwuba RI, Sodeinde $\mathrm{O}$, Anumudu $\mathrm{Cl}$, Omosun $\mathrm{YO}$, Odaibo AB, Holder AA Nwagwu M: The human immune response to Plasmodium falciparum includes both antibodies that inhibit merozoite surface protein 1 secondary processing and blocking antibodies. Infect Immun 2002, 70:5328-5331

17. Bergmann-Leitner ES, Duncan EH, Mullen GE, Burge JR, Khan F, Long CA, Angov $E$, Lyon JA: Critical evaluation of different methods for measuring the functional activity of antibodies against malaria blood stage antigens. Am J Trop Med Hyg 2006, 75:437-442.

18. Mclntosh RS, Shi J, Jennings RM, Chappel JC, de Koning-Ward TF, Smith T, Green J, van Egmond M, Leusen JH, Lazarou M, van de Winkel J, Jones TS, Crabb BS, Holder AA, Pleass RJ: The importance of human FcgammaRI in mediating protection to malaria. PLoS Pathog 2007, 3(5):e72.

19. Omosun YO, Adoro S, Anumudu Cl, Odaibo AB, Uthiapibull C, Holder AA, Nwagwu M, Nwuba Rl: Antibody specificities of children living in a malaria endemic area to inhibitory and blocking epitopes on MSP-1 ${ }_{19}$ of Plasmodium falciparum. Acta Trop 2009, 109:208-212.

20. Uthaipibull C, Aufiero B, Syed SE, Hansen B, Guevara Patino JA, Angov E, Ling IT, Fegeding K, Morgan WD, Ockenhouse C, Birdsall B, Feeney J, Lyon JA, Holder AA: Inhibitory and blocking monoclonal antibody epitopes on merozoite surface protein 1 of the malaria parasite Plasmodium falciparum. J Mol Biol 2001, 307:1381-1394.

21. Corran PH, O'Donnell RA, Todd J, Uthaipibull C, Holder AA, Crabb BS, Riley EM: The fine specificity, but not the invasion inhibitory activity, of 19-kilodalton merozoite surface protein 1-specific antibodies is associated with resistance to malarial parasitemia in a cross-sectional survey in The Gambia. Infect Immun 2004, 72:6185-6189.

22. Nwuba RI, Adoro SA, I AC, Odaibo AB, Omosun $Y$, Holder AA, Nwagwu M: Specificities of antibodies to Plasmodium falciparum merozoite surface protein-1. the 10th International Congress of Parasitology: 2002; Vancouver, Canada 2002, 477-486.

23. Okech BA, Corran PH, Todd J, Joynson-Hicks A, Uthaipibull C, Egwang TG, Holder AA, Riley EM: Fine specificity of serum antibodies to Plasmodium falciparum merozoite surface protein, PfMSP-1(19), predicts protection from malaria infection and high-density parasitemia. Infect Immun 2004, 72:1557-1567.

24. Holder AA, Guevara Patino JA, Uthaipibull C, Syed SE, Ling IT, ScottFinnigan T, Blackman MJ: Merozoite surface protein 1, immune evasion, and vaccines against asexual blood stage malaria. Parassitologia 1999, 41:409-414.

25. John CC, O'Donnell RA, Sumba PO, Moormann AM, de Koning-Ward TF, King CL, Kazura JW, Crabb BS: Evidence that invasion-inhibitory antibodies specific for the 19-kDa fragment of merozoite surface protein-1 (MSP-1 $\left.{ }_{19}\right)$ can play a protective role against blood-stage Plasmodium falciparum infection in individuals in a malaria endemic area of Africa. J Immunol 2004, 173:666-672.

26. Morgan WD, Frenkiel TA, Lock MJ, Grainger M, Holder AA: Precise epitope mapping of malaria parasite inhibitory antibodies by TROSY NMR crosssaturation. Biochemistry 2005, 44:518-523.

27. Morgan WD, Lock MJ, Frenkiel TA, Grainger M, Holder AA: Malaria parasiteinhibitory antibody epitopes on Plasmodium falciparum merozoite surface protein-1(19) mapped by TROSY NMR. Mol Biochem Parasitol 2004, 138:29-36

28. al-Yaman F, Genton B, Reeder JC, Anders RF, Smith T, Alpers MP: Reduced risk of clinical malaria in children infected with multiple clones of Plasmodium falciparum in a highly endemic area: a prospective community study. Trans R Soc Trop Med Hyg 1997, 91:602-605.

29. Farnert A, Rooth I, Svensson, Snounou G, Bjorkman A: Complexity of Plasmodium falciparum infections is consistent over time and protects against clinical disease in Tanzanian children. J Infect Dis 1999, 179:989-995.

30. Nwagwu M, Anumudu CA, Sodeinde O, Ologunde CA, Obi TU, Wirtz RA Gordon DM, Lyon JA: Identification of a subpopulation of immune Nigerian adult volunteers by antibodies to the circumsporozoite protein of Plasmodium falciparum. Am J Trop Med Hyg 1998, 58:684-692.

31. Ntoumi F, Mercereau-Puijalon O, Luty A, Georges A, Millet P: High prevalence of the third form of merozoite surface protein-1 in Plasmodium falciparum in asymptomatic children in Gabon. Trans $R$ Soc Trop Med Hyg 1996, 90:701-702.

32. Miller LH, Roberts T, Shahabuddin M, McCutchan TF: Analysis of sequence diversity in the Plasmodium falciparum merozoite surface protein-1 (MSP-1). Mol Biochem Parasitol 1993, 59:1-14.

33. Burghaus PA, Holder AA: Expression of the 19-kilodalton carboxy-terminal fragment of the Plasmodium falciparum merozoite surface protein-1 in Escherichia coli as a correctly folded protein. Mol Biochem Parasitol 1994, 64:165-169.

34. Holder AA, Lockyer MJ, Odink KG, Sandhu JS, Riveros-Moreno V, Nicholls SC, Hillman Y, Davey LS, Tizard ML, Schwarz RT, Freeman RR: Primary structure of the precursor to the three major surface antigens of Plasmodium falciparum merozoites. Nature 1985, 317:270-273.

35. Ockenhouse CF, Angov E, Kester KE, Diggs C, Soisson L, Cummings JF, Stewart AV, Palmer DR, Mahajan B, Krzych U, Tornieporth N, Delchambre M, Vanhandenhove M, Ofori-Anyinam O, Cohen J, Lyon JA, Heppner DG: Phase I safety and immunogenicity trial of FMP1/AS02A, a Plasmodium falciparum MSP-1 asexual blood stage vaccine. Vaccine 2006, 24:3009-3017.

36. Ogutu BR, Apollo OJ, McKinney D, Okoth W, Siangla J, Dubovsky F, Tucker K, Waitumbi JN, Diggs C, Wittes J, Malkin E, Leach A, Soisson LA, Milman JB, Otieno L, Holland CA, Polhemus M, Remich SA, Ockenhouse CF, Cohen J, Ballou WR, Martin SK, Angov E, Stewart VA, Lyon JA, Heppner DG, Withers MR: Blood stage malaria vaccine eliciting high antigen-specific antibody concentrations confers no protection to young children in Western Kenya. PLOS ONE 2009, 4:e4708.

37. Franks S, Koram KA, Wagner GE, Tetteh K, McGuinness D, Wheeler JG, Nkrumah F, Ranford-Cartwright L, Riley EM: Frequent and persistent, asymptomatic Plasmodium falciparum infections in African infants, characterized by multilocus genotyping. J Infect Dis 2001, 183:796-804

38. Wickramasinghe SN, Abdalla SH: Blood and bone marrow changes in malaria. Baillieres Best Pract Res Clin Haematol 2000, 13:277-299.

39. Smith T, Felger I, Beck HP, Tanner M: Consequences of multiple infection with Plasmodium falciparum in an area of high endemicity. Parassitologia 1999, 41:247-250.

40. May J, Falusi AG, Mockenhaupt FP, Ademowo OG, Olumese PE, Bienzle U, Meyer CG: Impact of subpatent multi-species and multi-clonal 
plasmodial infections on anaemia in children from Nigeria. Trans $R$ Soc Trop Med Hyg 2000, 94:399-403.

41. Contamin H, Fandeur T, Rogier C, Bonnefoy S, Konate L, Trape JF,

Mercereau-Puijalon O: Different genetic characteristics of Plasmodium falciparum isolates collected during successive clinical malaria episodes in Senegalese children. Am J Trop Med Hyg 1996, 54:632-643.

doi:10.1186/1475-2875-9-287

Cite this article as: Ngoundou-Landji et al: Fine specificity of anti-

$\mathrm{MSP}_{19}$ antibodies and multiplicity of Plasmodium falciparum Merozoite Surface Protein 1 types in individuals in Nigeria with sub-microscopic infection. Malaria Journal 2010 9:287.

Submit your next manuscript to BioMed Central and take full advantage of:

- Convenient online submission

- Thorough peer review

- No space constraints or color figure charges

- Immediate publication on acceptance

- Inclusion in PubMed, CAS, Scopus and Google Scholar

- Research which is freely available for redistribution

Submit your manuscript at www.biomedcentral.com/submit
C Biomed Central 